\title{
Mini-Abdominoplasty after Conservative Excision of Extensive Caesarean Scar Endometriosis
}

\author{
Jayanthi R. ${ }^{1}$, Iysverya G.T. ${ }^{2}$, Prasannapriya K. ${ }^{3}$ \\ 1,2,3 Department of Obstetrics and Gynaecology, Meenakshi Medical \\ College Hospital and Research Institute, Tamil Nadu, India.
}

\section{PRESENTATION OF CASE}

32-year-old para-2, live-2, prev-2, LSCS (Lower Segment Caesarean Section), LCB (Last Child Birth)-8 yrs. back, sterilized woman presented with complaints of increased abdominal pain during her cycles, more over the supra pubic transverse scar $^{1}$ for last 3 years. Pain is aggravated during and after menstruation and nonradiating. Her menstrual cycles were regular, with average flow, with severe dysmenorrhea which used to get relieved for some time on taking some analgesics. On examination her vitals were within normal limits. Abdominal examination revealed a hypertrophied supra pubic transverse scar which was tender, ${ }^{1}$ indurated and not warm. Uterus corresponds to 12 -weeks size. Systemic examination was within normal limits. Speculum examination was normal. Bimanual examination showed cervix flushed with anterior vaginal wall, uterus was felt anterior and was corresponding to 12-weeks size.

All haematological and biochemical investigations were within normal limits. CA 125 - $40 \mathrm{U} / \mathrm{mL}$. Ultrasound showed irregular ovoid hypo-echoic lesion in pelvis at the level of body of uterus of size $3.8 * 1.8 \mathrm{~cm}$ deep to the bub cutaneous tissue. Pap smear, negative for intra epithelial lesions. MRI (Magnetic Resonance Imaging) pelvis shows deformity in the anterior wall of myometrium and adjacent endometrium of the uterus which is adherent to the adjacent peritoneum and anterior abdominal wall muscle. ${ }^{2}$ Focal thickening of anterior abdominal wall muscle with mixed intense lesion of size $4.7 * 2.5 * 2.0 \mathrm{~cm}$ showing small T1 and T2 hyper intense cystic areas within.
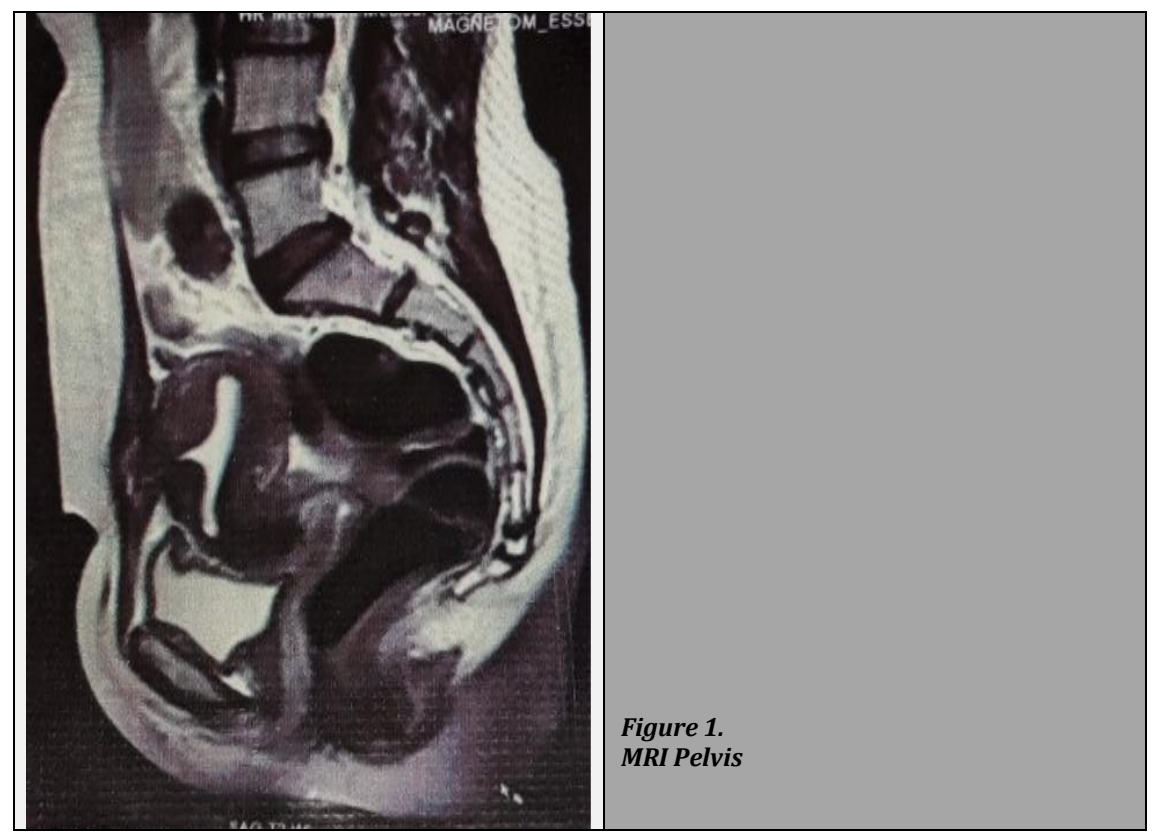

Corresponding Author: Dr. Prasannapriya $K$.

Department of Obstetrics and Gynaecology, Meenakshi Medical College Hospital and Research Institute, Tamil Nadu, India. E-mail:Priyak840@gmail.com

DOI: $10.14260 / \mathrm{jemds} / 2020 / 768$

How to Cite This Article:

Jayanthi R, lysverya GT, Prasannapriya K. Mini-abdominoplasty after conservative excision of extensive caesarean scar endometriosis. J Evolution Med Dent Sci 2020;9(46):3506-3508, $10.14260 / j e m d s / 2020 / 768$ DOI:

Submission 10-07-2020,

Peer Review 01-10-2020,

Acceptance 08-10-2020,

Published 16-11-2020.

Copyright (C) 2020 Jayanthi R. et al. This is an open access article distributed under Creative Commons Attribution License [Attribution 4.0 International (CC BY 4.0)] 

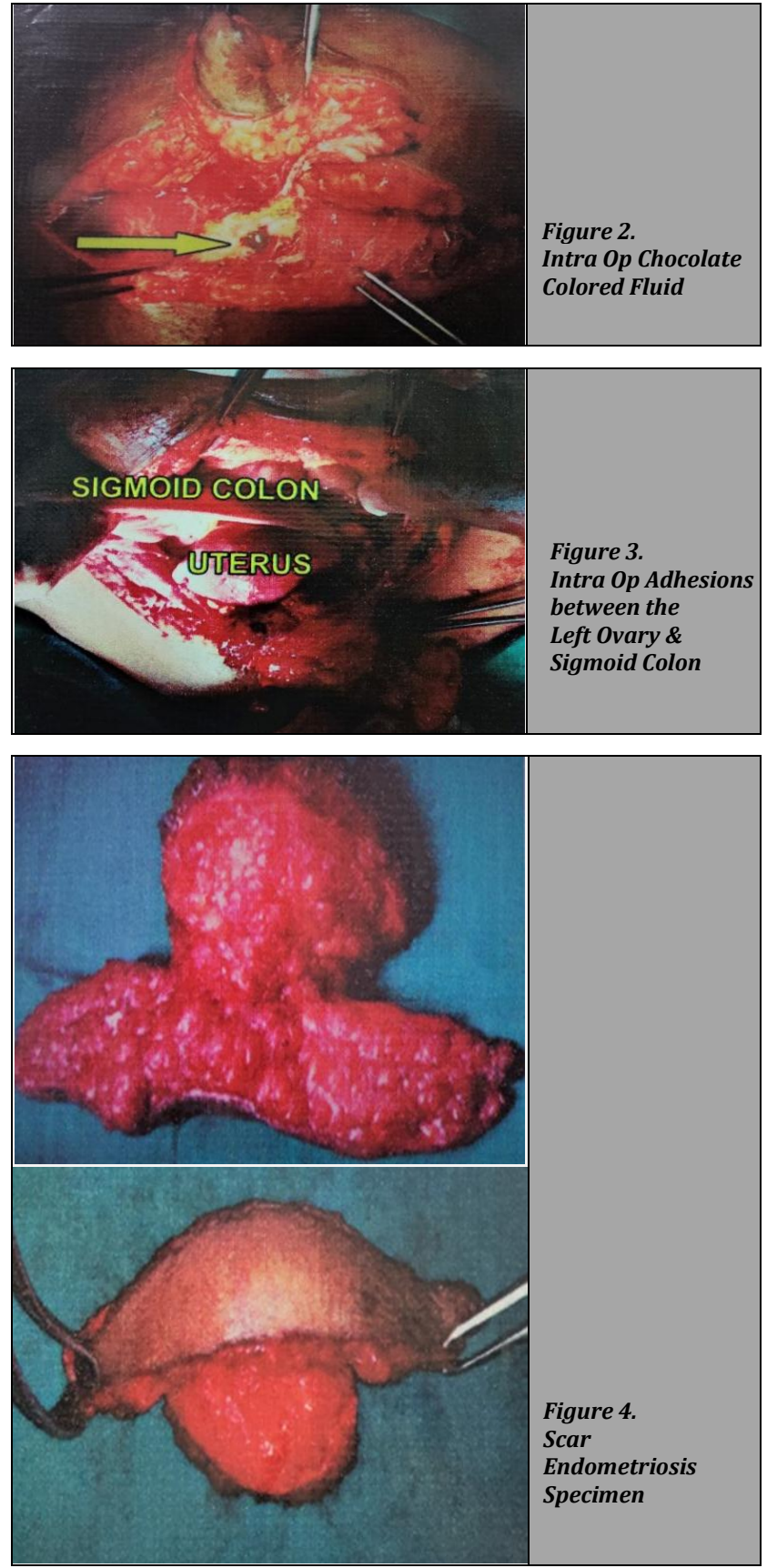

DISCUSSION OF MANAGEMENT

Patient underwent staging laparotomy. An elliptical incision was made over the scar. Induration of about $5.4 \mathrm{~cm}$ extending laterally and vertically around the scar was seen. Indurated scar tissue involving sub cutaneous tissue, rectus sheath and rectus muscle, extending up to the anterior wall of uterus was excised $^{3}$ and the edges were electro cauterized. While dissecting the fibrosed scar tissue, chocolate colour fluid was drained. Adhesions were extending from infundibulopelvic ligament to the left ovary to sigmoid colon posteriorly which was released. Bladder was adherent to scar tissue, which was also dissected. Bilateral ovaries and tubes were found to be normal. Rectus sheath was sutured. $15 \times 7.5 \mathrm{~cm}$ Prolene mesh was kept and fixed to rectus sheath. Suction drain was placed. Subcutaneous tissue and skin were sutured.
Patient was started on hormone therapy. During the $1^{\text {st }}$ year follow up period neither recurrence nor functional problems occurred.

\section{PATHOLOGICAL DISCUSSION}

\section{Histopathology Report}

- Multiple sections showed skin lined by stratified squamous epithelium with underlying dermis showing normal skin appendages.

- The deeper dermis showed cystically dilated endometrial gland surrounded by endometrial stromal cells embedded in a fibro collagenous stroma.

- Features consistent with scar endometriosis.

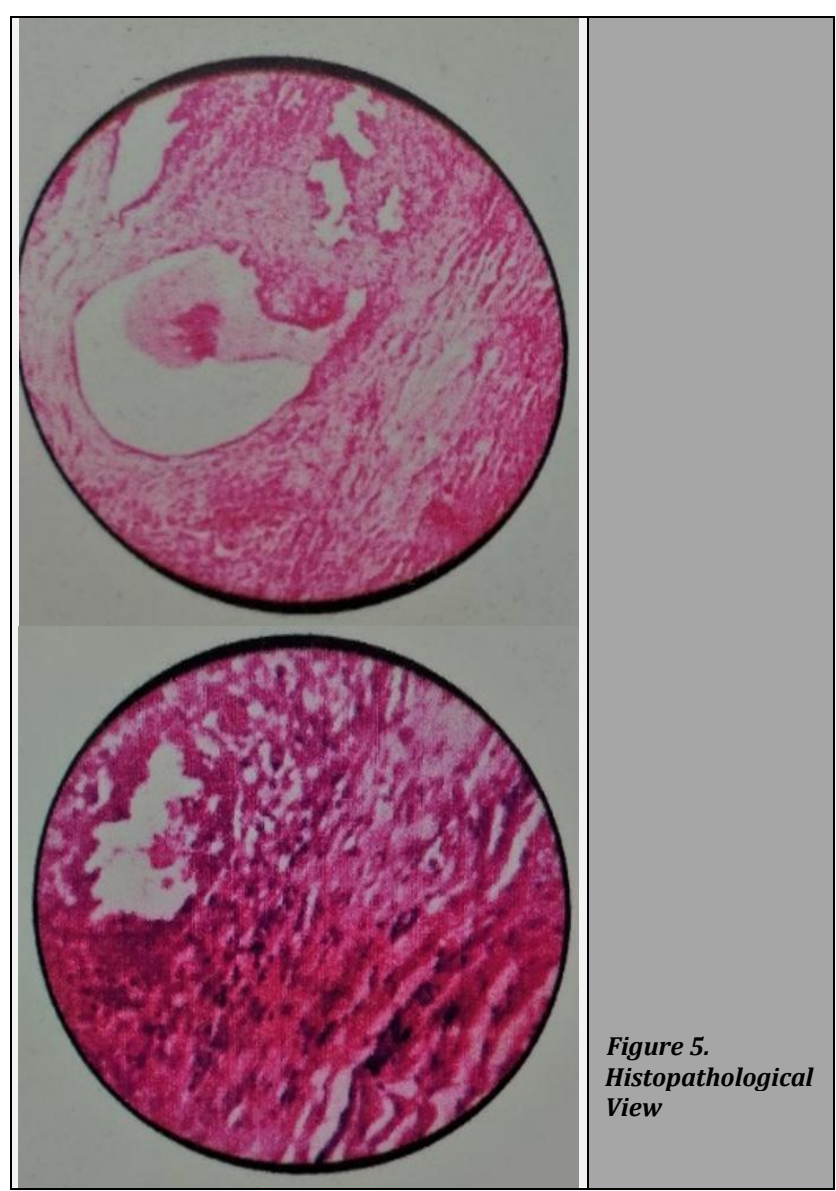

\section{DISCUSSION}

The endometriotic deposit is usually confined to the abdominal skin and sub cutaneous tissue with sparing of the muscle and rectus sheath. In fact, endometriosis involving the rectus abdominis is very rare $^{2}$. It was first described in 1984 by Amato and Levitt.

Time interval between the surgery and presentation has varied from 3 months to 10 years in different series 4 .

USG (Ultra-Sono-Graphy) and CT (Computed Tomography) may demonstrate and confirm the superficial nature of the mass. The gold standard is MRI which can detect small lesions and confirms its vascularity. 

therapy.

Extra pelvic endometriosis is not responsive to hormone

Application of mini-abdominoplasty made the patient satisfied with eradication of both the tumour and lower abdominal obesity without any of the problems associated with primary closure or full-abdominoplasty such as haematoma, seroma, necrosis of skin flap, and umbilicus and malposition of the umbilicus was reduced.

The patient should be followed up for recurrence.

Financial or other competing interests: None.

Disclosure forms provided by the authors are available with the full text of this article at jemds.com.

\section{REFERENCES}

[1] Danlelpour PJ, Layke JC, Durie N, et al. Scar endometriosis - a rare cause for a painful scar: a rare case report and review of the literature. Can J Plast Surg 2010;18(1):1920.

[2] Calo PG, Ambu R, Medas F, et al. Rectus abdominis muscle endometriosis report of two cases and review of the Literature. Ann Ital Chir 2012;20;S0003469X12018891.

[3] Park HM, Lee DG, Shin KJ, et al. Application of mini abdominoplasty after conservative excision of extensive cesarean scar endometriosis. Arch Plast Surg 2012;39(5):551-5.

[4] Kaplangolu M, Kaplanoglu DK, Ata CD, et al. Obstertric scar endometriosis: retrospective study on 19 cases \& review of the literature. Int Sch Res Notices 2014;2014:417042. 